\title{
PROTECTION OF GENETIC RESOURCES IN CENTRAL AND EASTERN EUROPE
}

\author{
H.-P Grunenfelder \\ PRO SPECIE RARA, Schneeberstraße 17, CH - 9000 St. Gallen, SWITZERLAND
}

\section{SUMMARY}

The conditions affecting agriculture in the countries of Central and Eastern Europe are being fundamentally changed by the transformation of the economy in that region. Rare breeds of domesticated animals and varieties of cultivated plants are in danger of rapidly disappearing. The article describes the situation in several countries; it also presents the plan of action of the Swiss foundation, PRO SPECIE RARA, to preserve the endangered genetic and cultural heritage in situ.

\section{RESUME}

Suite à la réorganisation de l'économie dans les pays de l'Europe Centrale et Orientale, les conditions pour l'agriculture se trouvent, elles aussi, en plein bouleversement. D'anciennes rares races de bétail menacent de disparâltre à très court terme, tout comme des plantes végétales uniques. Larticle ci-dessous présente la situation dans certains pays et décrit le plan d'action de la Fondation Suisse PRO SPECIE RARA, dont le but est de sauvegarder in-situ l'héritage génétique et culturel en péril. 


\subsection{RESULTS OF THE ECONOMIC RESTRUCTURING}

Numerous old breeds of livestock and varieties of cultivated plants have been maintained until the present day in the countries of Central and Eastern Europe. The status of efforts to preserve these genetic resources varies greatly. In some cases, authorized state farms or agricultural cooperatives have taken on the work of preservation (Hungary), in part committed private persons (CSFR), and, in some cases, farmers who are partly outside of the profit economy (Poland and the Yugoslavian successor states).

Former conditions in these countries are changing rapidly because of the economic restructuring. The departure from the clumsy and complicated planned economy, with its many "niches", to the newly required self financing of individual farms has devastating effects on "less profitable", less intensively managed, old robust breeds and varieties. For example, in CSFR, due to the collapse of prices and uncertainty about the future of agricultural structures and markets, $80 \%$ of all sheep and $50 \%$ of all cows were slaughtered within one year.

The Eastern European countries are well aware of the natural diversity within their territories. They would be pleased to work towards preserving it. The available funds are, however, insufficient for even the most essential needs. A Czech minister summarized the situation as follows: "The protection of nature and ecology are the whipped cream on the cake; but, first, we need to bake bread.

Despite the marked danger to livestock breeds and plant varieties posed by the rapid changes in agriculture, there has been no unified action taken by the large ecological organizations. As a result, Pro Specie Rara took, on its own, at the beginning of 1991, the emergency measure of establishing a coordinating office in Prague for protection of biological and genetic diversity in Eastern Europe.

\subsection{THE SITUATION IN INDIVIDUAL COUNTRIES Poland:}

Polish agriculture was not collectivized; this allowed the survival of numerous old breeds of livestock and plant varieties. Due to the rapid economic changes, however, this diversity is being endangered before an inventory has been properly established. Since the conversion is not likely to take place in all the small farms simultaneously, the threat is rather middle term than imminent.

\section{Czechoslovakia:}

Agriculture was 97\% collectivized in Czechoslovakia. A few valuable old breeds were maintained by "outsiders" and producer cooperatives in marginally productive areas. Since January 1,1991 , farms have had to be financially independent. This led many to try out (seemingly) better performing varieties. Due to the recent slaughtering, even once sizable populations are now threatened by extinction (e.g. the Tsigai sheep). Only a few specimens of the Valachian sheep and the sturdy Bohemian Red Cow are left. Action is urgently needed in Czechoslovakia. In only two years, it may already have been decided what will survive the economic conversion.

\section{Hungary:}

Hungary is one of the pioneers in the protection of genetic resources. Maintenance of old domestic breeds has been required by the centrally planned economy since 1968; this was entrusted to agricultural cooperatives and state farms. Due to the economic restructuring and the lack of finances, the responsible parties follow this regulation less and less. Genetic preservation specialists have great doubts for the future.

\section{Yugoslavian Successor States:}

The formerly Yugoslavian states possess distinct depopulated areas. There, traditional breeds and varieties have been preserved to this day For instance, in the meadows of the Sava River, pigs of the original Turopolier breed are allowed to range in the woods. In the Bosnian mountains, there are still some true dwarf cattle. Last year veterinarians, breeders, and specialists for nature preservation founded a protective organization similar to Pro Specie Rara. However, jointly planned projects have been seriously disrupted by the war. 


\subsection{PRAGUE COORDINATION OFFICE}

It became clear that, with exception of Hungary, long-term correspondence partners of Pro Specie Rara often did not know each other A first step, therefore, was to establish contacts between these people and to help coordinate their work and interests. The Czech capital of Prague proved to be a favorable location for an office to carry this out: action is most urgently necessary in the CSFR, Prague is centrally located and is closer to the Pro Specie Rara headquarters in Switzerland than, for example, Vienna. In addition, language problems are at a minimum there because many Czechs speak several Western and Eastern European languages.

After an unsuccessful attempt to instigate joint action by international nature protection organizations, representatives of Pro Specie Rara decided to act independently Initially, the Institute for Environmental in Prague offered to host the coordinating office. On January 2,1991, the coordinating office began work under the name "Eko Team Praha". Since April,1991, the office has been located at the "Center for Ecological Information, Prague". It is led by the agronomist Vladimir P Kaminek

The Eko Team analyzes projects, plans activities, prepares documentation and conduets administrative contacts with the government from the coordinating office. Members of decentralized projects also belong to the Eko-Team; this ensures an efficient project-centered approach with experts as project leaders.

\subsection{SURVEY OF ENDANGERED BREEDS IN THE CSFR}

\section{Small Livestock:}

Virtually nothing remains of the former diversity of goats; even the Colored Bohemian Goat (Hneda bezroha kratkosrsta koza), until recently widespread, has almost disappeared. Of the previous population of about 50,000 Tsigai Sheep (Cigaja), only an estimated 1-2,000 rema.in. An intervention has saved the last herd in the Czech Republic, numbering 200 sheep, for the time being. Only two breeding groups of the Original Walachian Sheep, with a total of two dozen animals, remain in the Czech Republic. Only -12remnants of the Improved Walachian Sheep (Zuslechtene Ualasska) still exist there. The Original Sumava Sheep (Ceska Selska) may have recently disappeared completely; a search is being continued among fanciers of the breed. The Presticke Pig still survives in small numbers in southwest Bohemia.

\section{Large Livestock:}

There is still a small herd of Bohemian Red Cows at the agricultural school in Lany. Small breeders are presumed to still have a few older individual animals. The Moravian Red Cow, Slovakian Red Cow and the yellow to grey Sumavsky Cow (Sumava) are already extinct. The Bohemian Pied Red Cow has been displaced almost completely by Red-Holstein Crosses. Isolated specimens of the Valachian Dwarf Cow may still exist in the formerly Slovakian regions of the Ukraine.

\section{Other Domesticated Animals:}

State institutions and private interests have concerned themselves with the Kladruby and Hutsul Horses. Despite minimal populations, neither breed is acutely endangered. On the other hand, the Prague Rat Dog, the Bohemian Herd Dog and the Czech Hen are all threatened by extinction.

\subsection{ROUGH SURVEY OF ENDANGERED BREEDS IN POLAND}

There are scientifically conducted genetic reserves of individual breeds in Poland: Konik and Hutsul Horses, the Podgorska variety of the Polish Red Cow, the Zlotnicka Pig and fowls, especially waterfowls. 
There is, however, a need for action to save less economically interesting small livestock. There may still be isolated surviving examples of the Sandomierska and Carpathian Goats kept by farmers (both are distinguished by their characteristic curly horns). There seems still to be a remnant of the Small Swiniarka Sheep. Further clarification is necessary to determine if the Polish Whitebacked Cow (Bialogrzbietka), the Small Polish Prick eared Pig (Polska mala ostroucha) and the Chubatka Crested Hen still exist. Little information is available in the cases of two hunting and two herd dog breeds. Further inquiries are necessary about pure populations of rare sheep breeds (Cakiel, Cigaja, Wrzosowka).

In addition to the preservation of presently endangered breeds, long term guarantees of existing measures and the further development of breeding programs for barely surviving populations (e.g. the Olkusch Sheep) are extremely important.

\subsection{ONGOING PROJECTS}

Fortunately, the efforts of Pro Specie Rara have met with much understanding and support from officials. The Environmental Ministry of the Czech Republic requested a report on the status of endangered breeds of domestic animals and possible protection measures. The report was delivered in September,1991. At the beginning of October,1991, the Viceminister of Agriculture, Dr. Richard Bartak, contacted Pro Specie Rara, during a visit to Switzerland, in order to discuss further details. The will to act exists, but the funds to carry it out are lacking.

Since then, the University of Agriculture Prague has committed itself to saving endangered breeds of large livestock in the CSFR, in particular, the Bohemian Red Cow. An organization is being formed to bring together all those interested in genetic preservation. Pro Specie Rara is attempting, with its coordinating office, to achieve a catalytic effect. In addition, it is also undertaking its own "in situ" projects: it is building up new breeding programs following procedures that have succeeded in Switzerland; the last remaining animals are purchased, gathered into new small groups and then loaned to interested participants; these participants are compensated for any ensuing reduction in yields. The breeding programs are broadly based through the use of as many stud males as possible; selective pairings protect against inbreeding. These breeding programs concentrate primarily on endangered breeds of small livestock. Projects are also being conducted with cultivated plants.

Similar projects, based on the experiences in the CSFR, are planned in Poland. Emergency measures are being prepared for Bosnia and Croatia that will be implemented when the war is over.

\subsection{CONCLUDING REMARKS .}

The need for action in the countries of Central and Eastern Europe is both great and urgent. The present state of currency exchange makes it possible to accomplish a great deal with comparatively little foreign financial assistance. Those involved hope for a rapid effect of the protection efforts.

The Swiss foundation Pro Specie Rara has taken, commensurate with the urgency of the problems, action outside of Switzerland's borders. It is, by all means, not alone in its efforts. The German partner organization (GEH) has taken on the breeding of the Walachian Sheep and the Austrian partner organization (VEREIN) the breeding of the similarly endangered Slovenian Steinschaf Both of these programs are outside the land of origin.

Efforts should now be coordinated throughout Europe. A European umbrella organization (Euro-Fund), presently being organized, is expected to take over this task. 


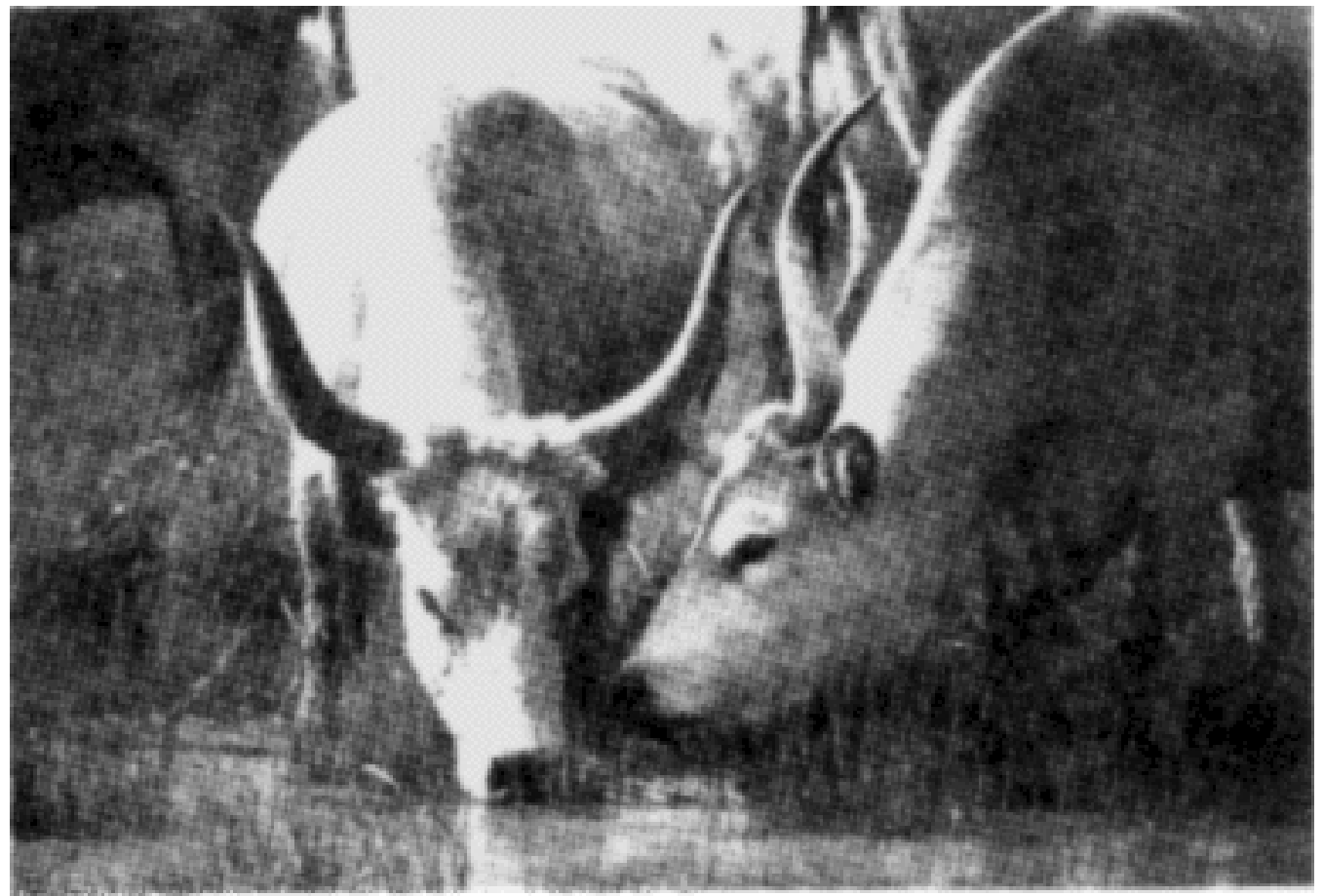

Steppic Gray callie (Hungary)

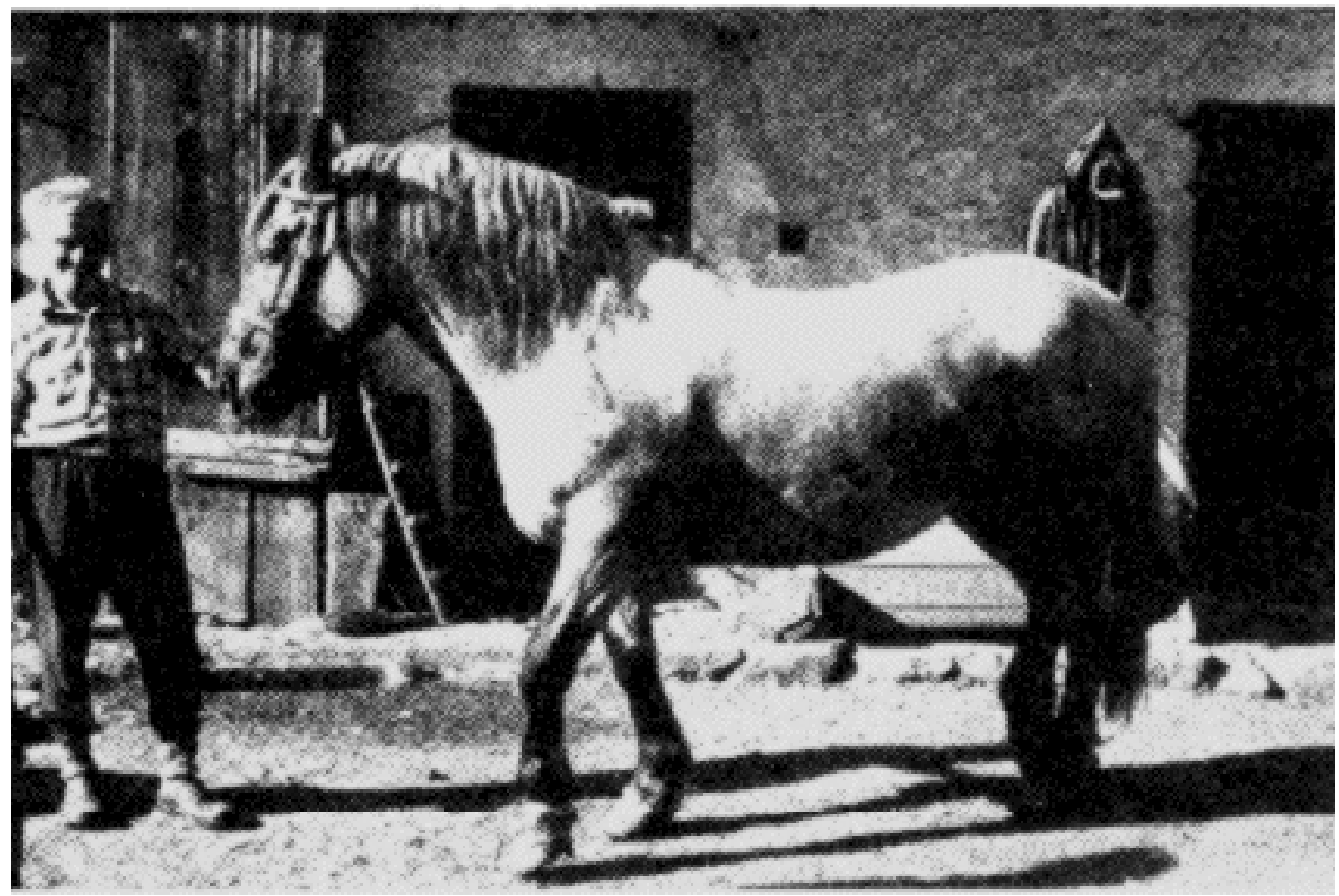

Kladruby torse (CSFR) 